Brit. F. industr. Med., 1968, 25, 68.

\title{
A Case of Acute Cadmium Pneumonitis: Lung Function Tests during a Four-year Follow-up
}

\author{
R. H. TOWNSHEND
}

From Sheffield Chest Clinic, Royal Infirmary, Sheffield, 6

Experimental animals which survive the acute pneumonitis that follows the inhalation of cadmium fume develop a perivascular and peribronchial fibrosis. Such fibrosis has not yet been described in man.

When a severe case of acute cadmium pneumonitis occurred in a welder, lung function tests were performed and chest radiographs were taken during the subsequent four years in order to observe whether changes signifying the onset of pulmonary fibrosis would develop.

The patient's lung function improved for six months after the accident, and during the subsequent three years there has been no deterioration.

\section{Case Report}

H. O'D., a welder aged 5I who had been unemployed for a year, found employment with a firm which specializes in rare metals. On his first day at work (September 3, 1963) he was given the job of welding together 'silver' plates using the argon arc technique. The method had been in operation in the factory for two years and was normally done by men who were not skilled welders. These men fixed the work in a vice on a bench but H. O'D. preferred to stand directly over his work and spent much of the day arranging a jig on the floor to hold the plates to his satisfaction.

He had some difficulty in adjusting the electric current and the argon gas flow to produce a good weld, and other workmen say that he made a large amount of greenish yellow smoke but, not being skilled welders, they did not like to offer advice on technique to an expert. With the job on the floor $\mathrm{H}$. O'D. was directly above the source of the smoke. $\mathrm{He}$ did not notice any irritant fumes and went home after the day's work feeling perfectly well.

At about 7.0 p.m. he had a sudden rigor and soon developed a burning pain in the chest with severe dyspnoea and a dry cough. Next day he was quite ill and his doctor diagnosed influenza. Fever persisted with pneumonic symptoms but the sputum was not bloodstained. After three weeks he had lost I 4 lb. $(6.3 \mathrm{~kg}$.) in weight. A chest radiograph at the Mass Radiography Unit showed gross bilateral

Received for publication August 7, 1967. pulmonary infiltrations and he was referred to the Chest Clinic.

Clinical examination on September 27 was negative except that he was slightly cyanosed at rest and there were fine crepitations at the base of the right lung. The urine contained a trace of albumin. The weight loss, radiographic appearance, and history of heavy cigarette smoking suggested a diagnosis of bronchial carcinoma and he was admitted to hospital for investigation.

On admission on September 30 his condition was unchanged. During the next 12 days he had a slight intermittent pyrexia, but his appetite rapidly improved and he began to gain weight. The blood count was normal, haemoglobin 104\%, and the sputum contained no significant organisms. Bronchoscopy on October 8 revealed no abnormality. Bronchial biopsy showed normal mucosa, glands, and cartilage. Tomography showed enlargement of the hilar glands and ill-defined shadows in both lower lobes but no discrete nodules.

The firm was approached and when it was learnt that the 'silver' plates were an alloy of $91 \%$ silver and $9 \%$ cadmium, it was realized that acute cadmium poisoning was the likely diagnosis. $\mathrm{He}$ continued to improve and regained his normal weight after three weeks. He returned to work in November 1963.

Investigations The first chest radiograph (Fig. I) taken 23 days after the incident showed extensive bilateral shadowing, suggesting severe pulmonary oedema, the lower and middle zones 


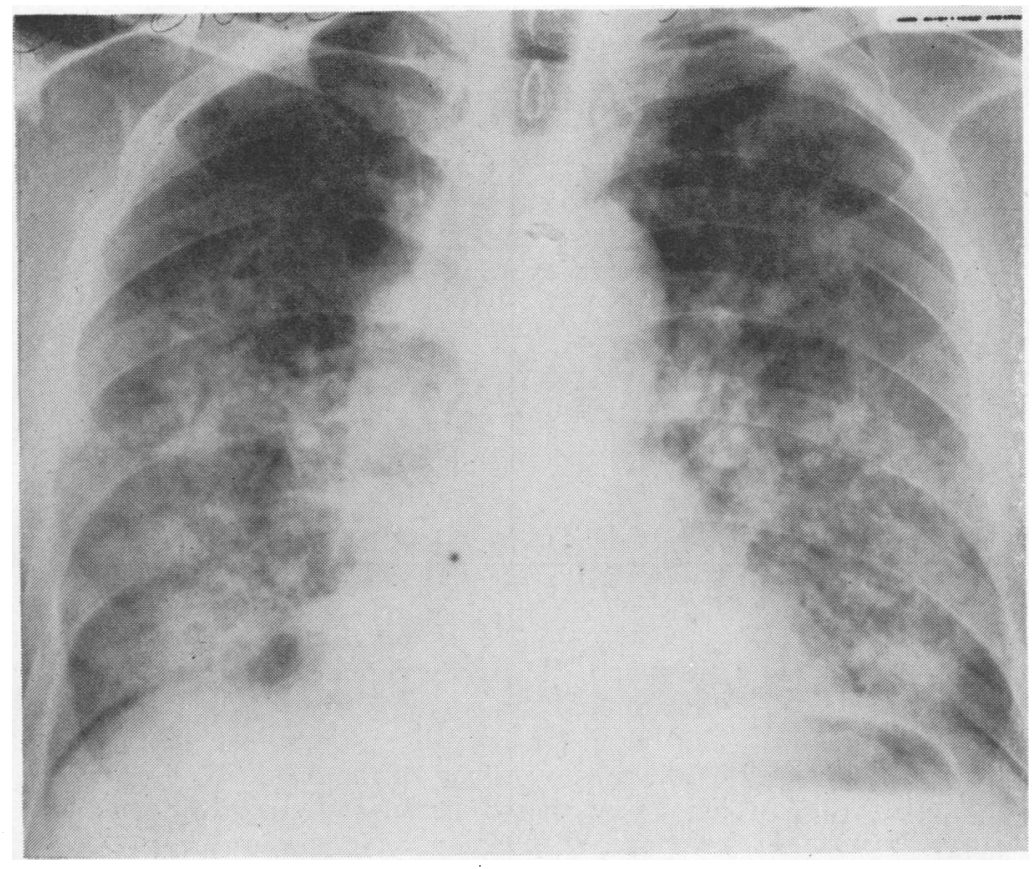

FIG. I. Chest radiograph taken 23 days after exposure to cadmium fume.

Fig. 2. Chest radiograph taken 4 years after exposure to cadmium fume.

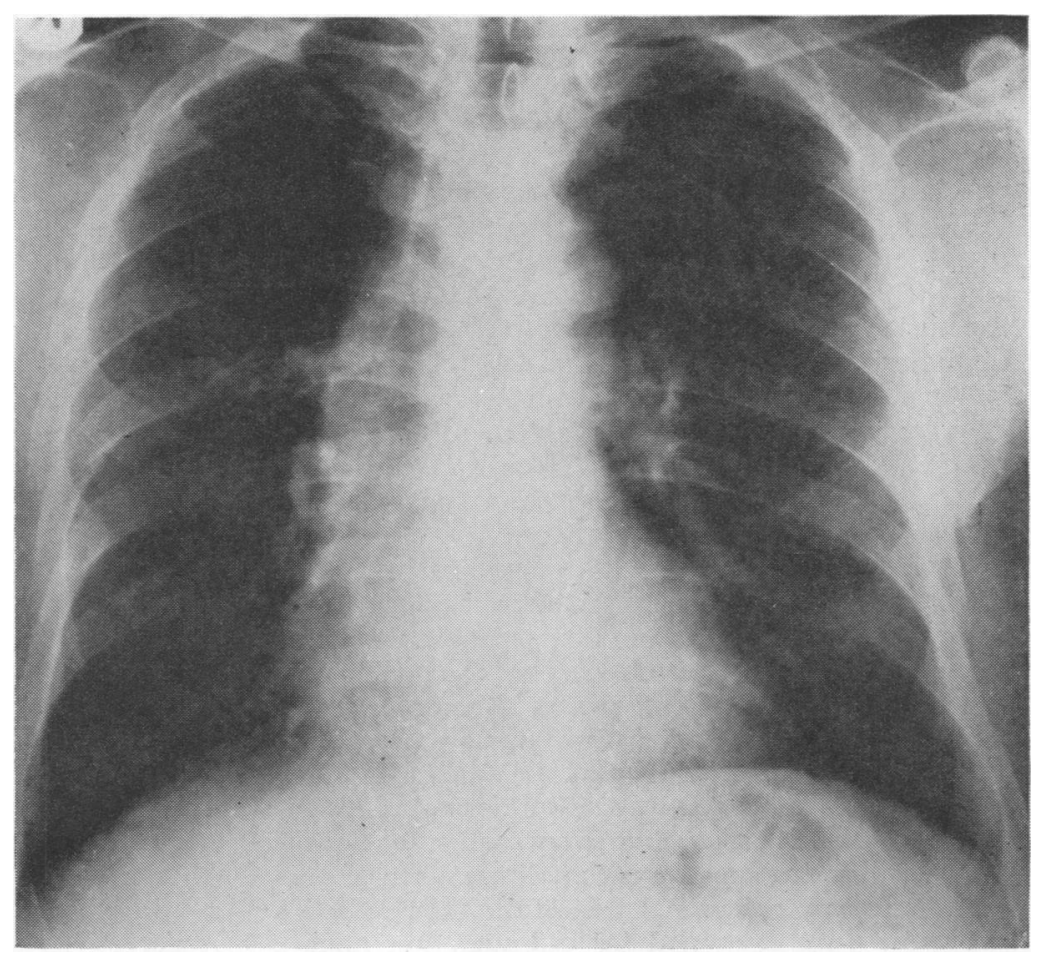


TABLE I

Serial Lung function Tests in a Case of Cadmium Pneumonitis

\begin{tabular}{|c|c|c|c|c|c|c|c|c|c|c|c|c|c|}
\hline & \multicolumn{13}{|c|}{ Time after Exposure to Cadmium } \\
\hline & $\begin{array}{c}6 \\
w k s\end{array}$ & $\begin{array}{c}10 \\
w k s\end{array}$ & $\stackrel{3}{m t h s}$ & $\begin{array}{l}4 \frac{1}{2} \\
\text { mths }\end{array}$ & $\begin{array}{c}6 \\
\text { mths }\end{array}$ & $\underset{m t h s}{I I}$ & $\begin{array}{c}\text { I3 } \\
\text { mths }\end{array}$ & $\begin{array}{c}14 \\
\text { mths }\end{array}$ & $\begin{array}{c}18 \\
\text { mths }\end{array}$ & $\begin{array}{c}2 \\
y r s\end{array}$ & $\begin{array}{c}3 \\
y r s\end{array}$ & $\begin{array}{l}3 \text { yrs, } \\
9 \text { mths }\end{array}$ & $\begin{array}{cc}4 & \overline{ } \\
y r s & \overline{\bar{c}}\end{array}$ \\
\hline $\begin{array}{l}\text { F.E.V.:-0 (ml.) } \\
\text { F.V.C. (ml.) } \\
\text { F.E.V.1.0 as \% of F.V.C. } \\
\text { F.V.C. \% of predicted value } \\
\text { Peak flow rate (1./min.) } \\
\text { CO diffusing capacity } \\
\text { (ml./min./mm. Hg) } \\
\text { CO } \% \text { removal } \\
\mathrm{PaCO}_{2}(\mathrm{~mm} . \mathrm{Hg})\end{array}$ & \begin{tabular}{|c|}
1323 \\
1533 \\
$86 \cdot 5$ \\
$47 \cdot 1$ \\
377 \\
$11 \cdot 0$ \\
$(15 \cdot 6)^{1}$ \\
$33 \cdot 0$ \\
$(45)^{1}$ \\
$41 \cdot 0$
\end{tabular} & $\begin{array}{c}1625 \\
1875 \\
86 \cdot 5 \\
57 \cdot 7 \\
430\end{array}$ & $\begin{array}{c}1725 \\
2092 \\
82 \cdot 5 \\
64 \cdot 4 \\
475\end{array}$ & $\begin{array}{c}1725 \\
1975 \\
87 \cdot 5 \\
60 \cdot 7 \\
450 \\
9 \cdot 1 \\
(15 \cdot 6)^{1} \\
38 \cdot 4 \\
(45)^{1}\end{array}$ & $\begin{array}{c}1905 \\
2267 \\
84 \cdot 0 \\
69 \cdot 4 \\
480\end{array}$ & \begin{tabular}{|c|}
1850 \\
2167 \\
$86 \cdot 0$ \\
$66 \cdot 6$ \\
443
\end{tabular} & \begin{tabular}{|c|}
1878 \\
2125 \\
$88 \cdot 5$ \\
$66 \cdot 0$ \\
430
\end{tabular} & \begin{tabular}{|c|}
2043 \\
2342 \\
$87 \cdot 0$ \\
$72 \cdot 7$ \\
458 \\
$16 \cdot 9$ \\
$(15 \cdot 3)^{1}$ \\
$47 \cdot 2$ \\
$(45)^{1}$
\end{tabular} & $\begin{array}{c}1905 \\
2267 \\
84 \cdot 0 \\
70 \cdot 4 \\
462\end{array}$ & \begin{tabular}{|c|}
1825 \\
2200 \\
$83 \cdot 0$ \\
$68 \cdot 9$ \\
438 \\
$12 \cdot 4$ \\
$(15 \cdot 0)^{1}$ \\
$41 \cdot 5$ \\
$(44)^{1}$
\end{tabular} & $\begin{array}{c}2015 \\
2325 \\
86 \cdot 5 \\
73 \cdot 6 \\
472\end{array}$ & \begin{tabular}{|c|}
1988 \\
2383 \\
$83 \cdot 2$ \\
$76 \cdot 1$ \\
503 \\
$23 \cdot 1$ \\
$(14 \cdot 5)^{1}$ \\
$51 \cdot 0$ \\
$(43)^{1}$
\end{tabular} & 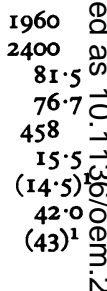 \\
\hline
\end{tabular}

${ }^{1}$ Predicted values of diffusing capacity and $\mathrm{CO} \%$ removal (Bates and Christie, 1964).

being most severely involved and the peripheral parts of the lungs relatively unaffected. After eight weeks, although there had been some clearing, there was still extensive patchy shadowing, but one month later only faint nodulation was visible. There has been no radiological change during the subsequent four years and it is impossible to be certain whether the faint nodulation which is still present (Fig. 2) is due to fibrosis caused by cadmium, or whether it results from his previous work as a welder. The patient had never had a chest radiograph before the accident.

The first lung function tests were performed six weeks after the accident (Table I). They showed a considerable decrease in the forced vital capacity (F.V.C.) with a corresponding decrease in the onesecond forced expiratory volume (F.E.V.1.0 ) but the ratio F.E.V.1.0 $/$ F.V.C. was normal at $86 \%$ showing that there was no obstruction of the airway but suggesting that the change was due to 'stiffness' of the lungs. The carbon monoxide diffusing capacity $\left(D_{\text {Lco }}\right)$ measured by the steady state end-tidal CO concentration method $\left(\mathrm{D}_{\mathrm{Lco}} \mathrm{SS}_{2}\right)$ (Bates and Christie, 1964) was well below the predicted value, as was the \% CO removal (Bates, I952).

Subsequent tests showed a progressive increase in the F.V.C. until six months after the accident, since when there has been no further improvement, and the figure is still less than $80 \%$ of the predicted value. The $D_{\text {Lco }}$ was still low at $4 \frac{1}{2}$ months but normal at 14 months and 4 years; the low two-year figure is probably unreliable as the fractional CO removal at the same time was almost normal. There has been no recent deterioration, and after four years the diffusing capacity is completely normal.

Six weeks after the inhalation of the fume, blood and urine were examined for cadmium but none was found. The urine contained a small amount of albumin and this was still present three years later. No cause for the albuminuria has been found. There are no urinary symptoms. Blood pressure has always been normal and the urine shows no evidence of infection. No low molecular weight protein was found in the urine at any time.

Four other men working in the same shop and one man who had left the factory in July 1963 were examined. They had all welded cadmium alloy at different times and for varying periods. They were all symptomless. None of them had noticed any dyspnoea or fever after welding. Their chest radiographs were quite normal, they had normal F.E.V.1.0 and F.V.C. values (Table II), and blood and urine specimens contained neither cadmium nor abnormal protein.

When the process was demonstrated it was apparent that yellow fumes of cadmium oxide were being produced and, to assess the risk, the firm arranged for Mr. King, Director of the Occupational Hygiene Service at Manchester, to measure the cadmium in the smoke.

TABLE II

Lung Function Tests IN THE OTHER WORKers

\begin{tabular}{l|c|c|c|c}
\hline & \multicolumn{4}{|c}{ Subject } \\
\cline { 2 - 5 } & B.B. & M.R. & D.G. & $A . E$. \\
\hline Age (yrs) & 21 & 42 & 40 & 22 \\
F.E.V.1. (ml.) & 3,563 & 3,225 & 3,175 & 4,950 \\
F.V.C. (ml.) & 4,633 & 5,117 & 3,900 & 5,525 \\
F.E.V.1.0 as \% of F.V.C. & $77 \cdot 0$ & $63 \cdot 0$ & $81 \cdot 5$ & $89 \cdot 5$ \\
F.V.C. \% of predicted & & & & \\
value & $93 \cdot 0$ & $104 \cdot 0$ & $88 \cdot 3$ & $92 \cdot 6$ \\
Peak flow rate (1./min.) & 497 & 560 & 618 & 650 \\
\hline
\end{tabular}


Extracts from Mr. King's report follow: 'The sheets of alloy were held in a jig at chest height. The welder, wearing a hood, worked with his face 6 in. to 9 in. from the work. The fume drifted against the hood and upwards, the hood protecting the wearer from any direct exposure. Atmospheric samples were taken in the path of the fume, about 6 in. from the source, with the sampling head sometimes touching the welder's hood. Sample I was under normal conditions (Table III). Sample 2 showed the effect of high current (high temperature).

TABLE III

Amount of Cadmium in Fume Under Different WELDING CoNDITIONS ${ }^{1}$

\begin{tabular}{|c|c|c|}
\hline Sample & Welding Conditions & Cadmium (mg./m. $\left.{ }^{3}\right)$ \\
\hline $\begin{array}{l}\text { I } \\
2\end{array}$ & $\begin{aligned} 90 \mathrm{~A} . & \text { 10 V. } \\
\text { 150 A. } & 22 \mathrm{~V} .\end{aligned}$ & $\begin{array}{r}64 \\
1,010\end{array}$ \\
\hline
\end{tabular}

${ }^{1}$ Measured by Mr. E. King

It was later discovered that $H$. O'D. had welded with a current of $100 \mathrm{~A}$. and the emission of cadmium must therefore have been between these two figures.

'H. O'D. was new to this type of alloy and his experience was in steel welding. He would have been accustomed to high working temperatures and gross emission of a harmless, brown iron oxide fume. He worked at floor level and with his face directly above the work was possibly exposed to a large amount of fume, even though he was wearing a welding hood.'

\section{Discussion}

This case is very similar to other reported cases of acute cadmium pneumonitis. Beton, Andrews, Davies, Howells, and Smith (1966) gave a very full account of cases in the literature and described an incident in which five men were exposed to cadmium fume when cadmium-plated bolts were melted with an oxyacetylene burner in an enclosed and unventilated space. All five developed pneumonic symptoms during the night but, in spite of this, three of them returned to work next day. One of these three, the oldest of the group, died on the fifth day. Necropsy revealed renal cortical necrosis and extensive pulmonary congestion with fibrinous intra-alveolar exudate and metaplasia of the cells lining the alveoli. The histology of the lungs was similar to that described in fatal cases by Christensen and Olson (1957) and by Paterson (1947) who examined the specimens from the cases reported by Bulmer, Rothwell, and Frankish (1938). Similar intra-alveolar changes were produced experimentally in guinea-pigs by Thurlbeck and Foley (1963), and in rats by Paterson (1947) who showed that, in animals which survived the acute pulmonary oedema, the lungs passed into a state of active cellular proliferation; a patchy fibrosis, chiefly peribronchial and perivascular, was the end result. Beton and his colleagues (1966) suggest that a similar fibrosis might be expected to follow acute cadmium pneumonitis in man, but no such case has yet been reported. If such fibrosis occurs in man, one would expect it to develop in the patient described here. When he was first seen three weeks after the accident the signs of pulmonary oedema were still very marked and even after two months the shadowing seen on the chest radiographs remained extensive. No case with radiographic changes persisting for so long after a single day's exposure to cadmium fume has previously been reported and it seems unlikely that this patient would have survived a much greater dose of the fume. The gradual improvement in the lung function tests during the first six months is thought to be due to the clearing of congestion and oedema. If fibrosis had developed it would have resulted after four years in a decline in the values of the F.V.C. and F.E.V.1.0, and a decreased $\mathrm{CO}$ diffusing capacity would also be expected. In fact the tests have tended to show a further slow improvement; the diffusing capacity remains normal and the F.V.C., although still low, is not deteriorating. It does not appear that appreciable fibrosis has developed in this case of severe acute cadmium pneumonitis.

I should like to thank Mr. E. King, Director of the Occupational Hygiene Service of Manchester University, for his help; the staff of the Respiratory Function Unit at the Sheffield Royal Infirmary for physiological measurements; and Miss T. I. Storey for clerical assistance.

\section{REFERENCES}

Bates, D. V. (1952). The uptake of carbon monoxide in health and in emphysema. Clin. Sci., 11, 21-32.

- and Christie, R. V. (1964). Respiratory Function in Disease, p. 5 I. Saunders, Philadelphia and London.

Beton, D. C., Andrews, G. S., Davies, H. J., Howells, L., and Smith, G. F. (1966). Acute cadmium fume poisoning. Brit. F. industr. Med., 23, 292-301.

Bulmer, F. M. R., Rothwell, H. E., and Frankish, E. R. (1938). Industrial cadmium poisoning. Canad. publ. Hith F., 29, 19-26.

Christensen, F. C., and Olson, E. C. (1957). Cadmium poisoning. Arch. industr. Hlth, 16, 8-13.

Paterson, J. C. (1947). Studies on the toxicity of inhaled cadmium. III. The pathology of cadmium smoke poisoning in man and in experimental animals. $\mathcal{f}$. industr. Hyg., 29, 294-301.

Thurlbeck, W. M., and Foley, F. D. (1963). Experimental pulmonary emphysema. The effect of intratracheal injection of cadmium chloride solution in the guinea pig. Amer. F. Path. 42, 43I-44I. 